\title{
God, divinities and spirits in African traditional religious ontology
}

\author{
Rev. Emeka C. Ekeke ${ }^{1}$ and Dr. Chike A. Ekeopara ${ }^{2}$ \\ ${ }^{1}$ Lecturer, Department of Religious Studies, University of Calabar, Pmb1115 Calabar, Crossriver \\ State, Nigeria, Email revekekemekus@yahoo.com \\ ${ }^{2}$ Senior Lecturer, Department of Religious Studies, University of Calabar, Pmb1115 Calabar, \\ Crossriver State, Nigeria.
}

\begin{abstract}
The concept of God, divinities and spirits in African traditional religious ontology has been so misunderstood by many scholars to the point of seeing Africans as people who did not know the Supreme Being nor worship Him. This paper seeks to examine how Africans conceive of the Supreme Being, divinities and spirits. The paper shows that the concept of God is not strange to Africans but in traditional Africa there is no atheist. It sees the divinities as beings who receive authority from the Supreme Being to serve in the unitary theocratic system of government. The paper sees the spirits as strangers, foreigners and outsiders in the category of things that should be defeated using spiritual powers.
\end{abstract}

Keywords: Religious Ontology, African tradition, Divinities, Spirits

\section{INTRODUCTION}

The concept of God, divinities and spirits in African traditional religious ontology has been a controversial and misunderstood concept. Various factors led to this controversy and misunderstanding, such as prejudice by Western scholars who measured African traditional religious concept with Christianity. Other factors include lack of indebt study of African religion leading to hasty conclusion. Most of those who came to study the religions of Africa were armchair scholars who depended on data from missionaries who themselves concentrated in one community or tribe. They used the scanty information derived from one or two localities in Africa to draw conclusion about the ontology of God, divinities and spirits in Africa. These armchair scholars went as far as believing that the sub-Saharan Africa is one country with one religious belief and practice.

This misunderstanding continued until indigenous African scholars like John S. Mbiti and E. Bolaji Idowu, in 1970s and 1980s, set out to refute some of the erroneous claims about African religions. They echoed the fact that "Africans had known God before the missionaries came" (Ray XI). This view gave Africans and their religion, which was battered and shattered by the missionaries who condemned and denigrated their religion, a new hope and integrity.

In this paper, our attention is drawn to the fact that there are realities in African religion which has not been properly echoed by Africans themselves especially those Eurocentric ones whose religious inclination has blinded them to the fact that Africans are not strangers to the worship of One True God Supreme Being, who is called by different names in Africa.

This paper also shows the position of the divinities and spirits in African religious metaphysics stressing that their belief in these other beings do not in any way contradict their belief in the Supreme Being as some opine. In most of the religions of the world, the concept of the Supreme Being is clearly spelt out just as it is in African religion with the divinities and spirits clearly set forth as messengers of the Supreme Being. This work is therefore focused on showing the place of God, divinities and spirits in African religious ontology.

God in African Religious Ontology: When we refer to the word 'God', we are talking about the living eternal Being who is the source of all living and whose life existed from the dateless past. He is self existed and is the one whose power sustains the universe. He is an all-knowing Being who knows and sees all things at the same time without any modern instrument. He even knows the end from the beginning.

This Great Being has revealed Himself in many different ways, "and human beings in particular have always felt His presence and responded to $\mathrm{Him}$ in worship" (Brown 1). This manifestation or revelation of God has brought about a living relationship 
between God and Man leading to what we now call religion. Some people who received this revelation have seen God as a personal Being such as the Jews and Muslims, while others like the Buddhists do not think of God as a personal Being at all.

The greatness of this Being has been described by many scholars, religious people and many religious scriptures. In describing God, Al-Ghazzali wrote:

$\mathrm{He}$ is the power and the kingdom and the glory and the majesty and to Him belongs creation and the rule over what He created: He alone is the Giver of life; $\mathrm{He}$ is omniscient, for $\mathrm{His}$ knowledge encompasseth all things, from the deepest depths of the earth to the highest heights of the heavens. The smallest atom in the earth or the heavens is known unto Him. He is aware of how the ants creep upon the hard rock in the darkness of the night. $\mathrm{He}$ perceives the movement of specks of dust in the air. He beholds the thoughts which pass through the minds of men, and the range of their fancies and the secrets of their hearts, by His knowledge, which was from aforetime (qtd in Brown 2).

The Arjuma's Hymn written in about $500-100$ BC in ancient Hindu Gita, expresses the same belief in the greatness of this great God and his relationship with humanity and the universe:

Why should they not revere You? ... You are the first Creator, Infinite, Lord of the gods, home of the Universe. You are the Imperishable. You are the last Prop-and-resting Place of the universe. You are the Knower and what is to be Known ... The whole universe was spun by You ... Your strength is infinite, Your power is limitless. You bring all things to their fulfillment: hence You are All ... You are the Father of the world of moving and unmoving things (qtd in Brown 3).

These descriptions as given above shows the extent of the greatness of this Supreme Being by many religions.

The greatness of this Supreme Being - God is also portrayed in African religions. The fact that there are no written scriptures by the votaries of African traditional religion, does not in any way mean that the concept of the Supreme Being does not exist in their ontology. John S. Mbiti explains that though the knowledge of God as the Supreme Being is not documented in any sacred book, yet it is "expressed in proverbs, short statements, songs, prayers, names, myths, stories and religious ceremonies" (African Religions and Philosophy 29). This means that for one to understand the concept of God - the Supreme Being in African, he has to study carefully the entirety of the culture of the people. This agrees with what Mbiti said, "One should not, therefore, expect long dissertations about God. But God is no stranger to African peoples, and in traditional life there are no atheists" (29). This is further supported by an Ashanti proverb which says "No one shows a child the Supreme Being. This proverb means that anyone born in Africa does not need to go to school to learn about the existence of the Supreme Being, but God's existence is known by all including children.

The Origin of Belief in God in Africa: There are divergent views of scholars as per the origin of religion. Some see religion as originating from fear. People saw the vastness of the universe and the rumblings of thunder and lightening and the vastness of the sea and so many other things that caused them fear and so developed faith in something that will shield them from what they feared. Others see religion as originating from magic while others see religion as the creation of the priestly class.

As there are divergent views of scholars concerning the origin of religion, in the same way many scholars have various views as per the origin of belief in God in Africa. Three important views exist which are here explained.

1. Through reflections on the universe, Africans came to believe in God.

This view has its bases on the fact that Africans believe in God as the Creator of the universe. This belief may have led them to reflect on the vastness of the universe. Their imagination led them to this conclusion that there must be a Supreme Being whose power not only created this vast and complex universe but also sustains it. They therefore began to give this being worship and adoration. Mbiti, writing in his work Introduction to African Religion, explains that the process of arriving at this conclusion of belief must have taken a long time "and there must have been many myths and ideas which tried to explain these mysteries of the world" (40).

2. Through realization of their own limitations Africans came to believe in God.

This second view or explanation of the origin of belief in God in Africa has its root in man's limitations and the insatiable nature of man's needs. Africans saw that they were limited and weak in many respects, including knowledge and power, particularly in the 
face of death, calamity, thunderstorms, earthquakes, mighty rivers and great forests which are beyond man to control. These limitations and powerlessness rather led them to speculate that there must be a Supreme Being who is superior to these other powers that can be drawn to help them through appeasement and or sacrifice. Mbiti argues that "this idea made it logical and necessary for man to depend on the one who was more powerful than people". (Introduction to African Religions, 41). This made Africans to feel that they needed the help of this Supreme Being in their experiences of limitations and powerlessness. This is the Great God that the Africans worship. It should be observed that the process of this formulation took a long period before it was actually conceptualized.

3. As Africans observed the forces of nature, they came to believe in God.

This third view of the origin of belief in God in Africa is so important because it has to do with the various forces of nature. From time immemorial; man has been in the habit of looking at the forces of nature with awe and reverence. This made man to worship these forces as having one supernatural power or another. As Africans looked at the weather, storms, thunder and lightening, and other phenomena such as day and night, the firmament, the sun, moon and stars, seeing their enormous benefit to man yet unreachable, the Africans began to associate the sky with a great God who is very close to man, supplying man's needs such as rain for his land to produce abundant fruit. Mbiti argues that this may be the reason "that God is so much associated with the sky and the heavens".

He argues further that:

It is very likely that ... [Africans] came to believe in God's existence through such a link between heaven and earth. Man was at the centre of the universe. Standing on the earth but looking up to the heavens, and that belief began to make sense and fit into man's continued attempts to understand and explain the visible and the invisible universe, the earthly and heavenly worlds of which man is the centre (Introduction to African Religions, 41, 42).

African religion centres on belief and practices. This knowledge of God through belief; became the cardinal point of the religion of Africans.

Attributes of God (Supreme Being) in Africa: Attributes of God refers to words or phrases ascribing traits, properties, qualities or characteristics to the
Supreme Being. These attributes are anthropomorphic in nature. This is because any religion that stripes the Supreme Being of anthropomorphic phenomenon will eventually end up as an abstract religion that does not have human feelings and is not fully realizable in the world.

Anthropomorphism is the ascribing of human character to God. J. Omosade Awolalu and P. Adelumo Dopamu explain that anthropomorphism has been found in all religions as a way of expressing ideas or concepts about the preternatural world of realities. For this reason, they argued that it cannot be accepted as a part of the structure of African religion (32).

As we study these attributes of God in Africa, we must be conscious of this fact that there are no sacred scriptures of African religion for us to consult and know what these attributes are, as one who wishes to study the attributes of God in Christianity or Islam will do. Rather attributes of God in African religion can be found in the songs, proverbs, sayings, recitals and liturgies of so many African people.

(a) God is real to Africans: Africans do not perceive of God as an abstract entity whose existence is in the mind. He is seen and perceived as a real personal entity whose help is sought in times of trouble and who is believed to be the protector of the people. The various names given to God in African attest to this. The fact that God is real to Africans is enshrined in the meaning of the name they call him. The Yoruba of Nigeria call God Olodumare or Edumere meaning "The King or Chief unique who holds the sceptre, wields authority and has the quality which is superlative in worth, and he is at the same time permanent, unchanging and reliable." Another Yoruba name for God is Olorun meaning "the owner of heaven" or "the Lord of heaven" showing God as the author of all things both visible and invisible.

The Igbo of Nigeria call God by these names Chukwu meaning "Source Being" which connotes "the Great One from whom being originates". Chineke meaning, "The Source Being Who creates all things". The Edo of Nigeria knows God as Osanobua or Osanobwa which means "the source of all beings who carries and sustains the world or universe". Among the Nupe of Nigeria God is called Soko which means "the creator or supreme deity that resides in heaven".

The Ewe and Fon people of Dahomey call God Nana Buluku which means the great ancient Deity. Among the Akon and Ga people of Ghana, God is known by 
these names: Odamankoma, meaning "He who is uninterruptedly, infinitely and exclusively fully of grace" or "He who alone is full of abundance or completeness" or "He who in His grace has completed everything in heaven and on earth". Nyame or Onyame meaning "if you possess or get him, you are satisfied" which expresses God as God of fullness or God of satisfaction.

Among the Mende people of Sierra-Leone God is called Ngewo which means "the eternal one who rules from above". (Awolalu and Dopamu 38-43).

These names were not created by Africans after the colonial era but shows how real God is to Africans. If God were not real to Africans how did they manufacture these names and given to the Being they do not know?

\section{b) God is unique in African religious ontology}

When the word unique is used in reference to the attribute of God in Africa we are looking at God as having no equal or non like Him and being the only One of its sort.

We earlier explained that the Yoruba people of Nigeria refer to God as Olodumare meaning "The king or chief unique, who holds the scepter, wields authority and has the quality which is superlative in worth, and he is at the same time permanent, unchanging and reliable". This description shows the uniqueness of God in Africa. Not only is God seen as unique but $\mathrm{He}$ is also seen as permanent, unchanging and reliable. This is why in Africa there are no images attributed to the Supreme Being. In most cases there are no temples except in few places, dedicated to the Supreme Being.

No body in Africa has produced any picture attributive to the Supreme Being because the concept of God is embedded deeply in their ontology that the Supreme Being is unique and nothing is comparable to Him. Idowu has this to say concerning the uniqueness of God:

The uniqueness of Deity is one reason why there are no images - graven or in drawing or in painting of him in Africa. Symbols there are copiously, but no images. The African concept of God, in this regard is an emphatic 'No one' and 'None' to the question, 'To whom then will you liken God or what likeness compare with Him? (African Traditional ... 152).

Alice Werner in describing Leza, the name used for the High God by the Baila, Botanga, and other tribes of Northern Zambia explains that Leza is described as "the One who does what no other can do" (51). In writing about the Ruanda people Werner described their Supreme Being (Imana) in a proverb thus: "There is none to equal Imana" (44). These descriptions show the uniqueness of the Supreme Being in African religious ontology.

Evans - Pritchard in his definite view of God, known as Kwoth among Nuer people of Sudan says:

The Nuer word we translate 'God' is Kwoth, Spirit ... We may certainly say that the Nuer do not regard the sky or any celestial phenomena as God, and this is clearly known in the distinction made between God and the sky in the expression spirit of the 'sky' and spirit who is in the sky'. Moreover, it would even be a mistake to interpret 'of the sky' and 'in the sky' too literally... They may address the moon, but it is God to whom they speak through it, for the moon is not regarded, as such, as Spirit or as a person. Though God is not [sky, moon, rain, and others]... He reveals Himself through them. (12).

Evans-Prichard has carefully explained that though the various natural phenomena are not God from the African concept of God, they are vehicles through which God reveals Himself to people. We still maintain that God is unique and that is how Africans see the Supreme Being.

\section{(c) God is Transcendent and Immanent}

These two words, transcendent and immanent could be seen as two sides of the same coin. Transcendent means that something is beyond what is natural and normal, and different from it. When Africans see God as transcendent, it means that (a) God is not limited to a particular place and time as human beings are. (b) It means that God lives outside the natural world in which human beings live. (c) It also means that human beings can never fully comprehend the will or thoughts of the Supreme Being. He is beyond their understanding. (d) It further means that God is always there first: $\mathrm{He}$ is the creator of all things and the initiator of all events. (e) Finally, it means that human beings feel awe when they remember the presence of God. He is good and trustworthy in a way that they are not (Brown 2).

As an immanent God, Africans see Him as God whose presence is felt by people within the natural world. This means that they feel his presence around their surroundings, and through what happens to them and their families. Africans see God as very present within the natural world to help protect and deliver his creation, although at the same time, He 
transcends the natural realm. When we say that God is immanent in the world, we are presenting an attribute that shows God as dwelling among us or within us.

So many writers especially the armchair scholars from the West argue that God in the African concept is far removed that they see Him as "Absentee Landlord". They conclude that though Africans have a faint knowledge of God, but that God is far removed from them so that they rather go to the divinity for help. This is a big error. You cannot emphasize God's remoteness to Africans to the exclusion of His nearness.

Awolalu and Dopamu argue that to the Africans "the transcendence and immanence of God are two divine attributes that are paradoxically complementary" (50). This is revealed in the Nupe song: "God is far away. God is in front, He is in the back". This Nupe song means that though God is not on earth yet $\mathrm{He}$ is very present, always, and everywhere. To show the immanence of God among the Yoruba of Nigeria they ask "What can you do in concealment that God's eyes do not reach?" And they also add another statement "He who steals under concealment, even though the eyes of the earthly ruler do not see him, those of the King of Heaven are looking at him" (Awolalu and Dopamu 51). The above sayings reveal the immanence of God in African religious ontology. They show that Africans believe that though God is transcendent, yet $\mathrm{He}$ is immanent.

d) In Africa God is Eternal and Immortal.

The Africans do not see the Supreme Being as One who will one day cease to be or one who will eventually die. They rather see Him as the eternal and immortal One who lives forever to satisfy the human soul. This is why "they hold that the Supreme Deity is the Ever-living Reality Whose Being stretches to eternity" (Awolalu and Dopamu 52). A Yoruba epithet of praise describes this eternal and immortal attribute of the Supreme Being in Africa: Oyigiyi Ota Aiku - "The mighty, immovable, hard, ancient, durable Rock that never dies".

The Kono people of Sierra Leone call God by the name Yataa which means that "God is the One you meet everywhere". They also call God by another name Meketa implying "the Everlasting One", "The One who remains and does not die" showing that people of many generations experience God living (Awolalu and Dopamu 52).
There are so many other great attributes of God in African religious ontology which we may not expatiate in this work such as: God is the absolute controller of the universe, God is Omnipotent, Omnipresent and Omniscient in Africa; the Supreme Being is one in Africa; God is good and merciful, and God is Holy.

The attributes as enumerated above are not the product of missionary activities or colonial era. They are part and parcel of Africans. Every child born into African culture grows with these concepts of God and he does not need to learn them because they are imbued in their folklores, myths, short stories, short sayings, proverbs, ceremonies and everything around them. These attributes show the place of the Supreme Being in the African traditional religious ontology. No one under any guise should say that Africans did not know God before colonial era or before the coming of the missionaries. The knowledge of God as the Supreme Being in Africa has been part of our culture from time immemorial.

Divinities in African Religious Ontology: The African religions partly recognize a group of being popularly known as divinities. These beings have been given various names by various writers such as 'gods', 'demigods', 'nature spirits', divinities, and the like. Mbiti explains that the term "covers personification of God's activities and manifestations, the so-called 'nature spirits', deified heroes, and mythological figures" (Concept of God in Africa, 117). This belief in divinities is a common phenomenon especially in West Africa, while in other parts of Africa; the concept is not succinctly expressed. This is what Francis O. C. Njoku means when he said, "The phenomenon of belief in divinities is not everywhere prominent in Africa" (125).

In West Africa where the concept is clearly expressed, there are so many of such divinities. In Yoruba pantheon, for example, Idowu explains that there are as much as 201, 401, 600, or 1700 divinities (Qtd in Njoku 127). In Edo of Nigeria, Mbiti narrates that there are as many divinities as there are human needs, activities and experiences, and the cults of these divinities are recognized as such. In his words "One [divinity] is connected with wealth, human fertility, and supply of children (Oluku); another is iron (Ogu), another of medicine (Osu), and another of death (Ogiuwu)" (Concepts of God in Africa, 119).

Divinities have been grouped into two major groups namely: the Principal Divinities and Minor Divinities. Principal divinities are regarded as part of the original 
order of things. Njoku sees these as being "co-eval with the coming into being of the cosmos" (126). They include such divinities as Sango or Amadioha thunder divinities for Yoruba and Igbo; Ani or Ala earth divinity among the Igbo, Aje in Idoma land and other solar divinities. The Dinka people of Sudan recognize Deng divinity associated with rain, fertility and others, Abak with mother role, Garang - perfect picture of father/son relationship. They also recognize Macardt - a divinity associated with death (127).

Nature of Divinities: There are two major schools of thought as regards the origin of divinities in African religious ontology. The first school of thought is led by John S. Mbiti. He argues that divinities were created by the Supreme Being. He explains that divinities "have been created by God in the ontological category of the spirits. They are associated with Him, and often stand for His activities or manifestation either as personifications or as the spiritual beings in charge of these major objects or phenomena of nature" (African Religions and Philosophy 75, 76). By this view of Mbiti and his group, divinities are under the Supreme Being in the order of things. They can also be seen as manifestations of the characteristics or attributes of the Supreme Being.

The second school of thought, championed by $E$. Bolaji Idowu, argues that divinities were not created but were brought out into being. In his words,

From the point of view of the theology of African traditional religion, it will not be correct to say that the divinities were created. It will be correct to say that they were brought into being, or that they came into being in the nature of things with regard to the divine ordering of the universe (169).

This view of Idowu may correspond to the Christian theology about the divinity of Christ. Christians believe that Christ was not created but came out (brought forth) from the Father and so shares almost all the attributes of the Father. This is why he is called the Son of God. In the same way, Idowu applies the same theology to the divinities. He explains that Orisa-nla (the arch-divinity among the Yoruba) "is definitely a derivation partaking of the very nature and metaphysical attributes of Olodumare" (169). This is why the Yoruba people call him "Deity's son and deputy, vested with the power and authority of royal sonship "(169). In Benin of Nigeria, Olokun the arch-divinity is regarded as the son of Osanobwa, which means a son vested with power and majesty by his father. Among the Akan people of Ghana, all their divinities are regarded as sons of Onyame. Idowu therefore argues that "it is in consequence of this derivative relationship that these divine "beings" are entitled to be called divinities or deities" (169).

A careful look at these two schools will show that Idowu was applying the Christian theological principle to African traditional religion by declaring that the divinities were not created just as Christians believe that Jesus Christ was not created.

Chike Ekeopara lays his weight behind Idowu by declaring that the divinities were not created and adds "Divinities are brought into being to serve the will of the Supreme Being" (19).

There is an agreement among scholars that divinities are divided into two groups. One group being spirits and the other group being human beings of the distant past, who, by their heroic activities where deified. Our argument here is that if all divinities were not created, it means that those heroic human beings of the distant past who were deified were not created. This will run contrary to the general belief of Africans concerning the Supreme Being whom alone has no beginning and no ending in African religious theology. If the divinities are said to posses the same uncreated nature, then there must be equality between them in some sense. But we have submitted in this paper that in Yoruba of Nigeria, the name Olodumare, a name given to the Supreme Being, means a king or chief who wields authority and is "unique". This uniqueness means one of his kinds. None is comparable to $\mathrm{Him}$. He is unchangeable and reliable.

It therefore follows that if God is unique then every other creature must be different from Him. They are regarded as divinities. Their being called divinities is because they are sometimes the personification of the natural forces or the manifestation of the Supreme Being. This researcher therefore, agrees with John S. Mbiti that divinities "have been created by God initially as spirits... [and] are largely the personifications of natural objects and forces... of the universe" (Introduction to African Religion, 66)

\section{Relationship between Divinities and Supreme Being}

1. They are created "beings". As created beings, they are subordinate to the Supreme Being. 
2. They are derivations from Deity. The divinities do not have independent existence or absolute existence, but derive their being from the Supreme Being. This means that "since divinities derive their being from the Supreme Being, their powers and authorities are meaningless apart from Him (Ekeopara 19)

3. They are given functions to perform: Divinities do not perform duties against the will of the Supreme Being rather they are obedient to the command of the Supreme Being. Various communities of Africa who believe in divinities have their local names for each divinity depending on the function the divinity performs. In Yoruba Jakuta, the divinity responsible for Wrath-one who hurls or fights with stones", is known in Nupe as Sokogba - God's axe. Among the Igbo Ala or Ani - Earth, is the arch-divinity responsible for the fertility of the soil.

4. Another important relationship between the divinities and Supreme Being in Africa is that the divinities serve as "functionaries in the theocratic government of the universe" (Idowu 170). This means that the various divinities have been apportioned various duties to perform in accordance with the will of the Supreme Being. This is clearly shown by Idowu in his book Olodumare ... where he explained that in Dahomey, Mawu-Lisa is regarded as an arch-divinity who apportioned the kingdoms of the sky, the sea, and the earth to six of his off-springs. He made his seventh child Legba, the divine messenger and inspector-general in African pantheon (80). This also means that the divinities are ministers with different definite portfolios in the monarchial government of the Supreme Being. They therefore serve as administrative heads of various departments (Idowu, African Traditional Religion, 170).

5. Divinities are Intermediaries between man and the Supreme Being. They have therefore become channels through which sacrifices, prayers and offerings are presented to the Supreme Being. In Africa, there are no images of the Supreme Being but the divinities are represented with images temples or shrines. Idowu explains that the divinities do not prevent Africans from knowing or worshiping the Supreme Being directly as some erroneously claim, but

constitute only a half-way house which is not meant to be permanent resting place for man's soul. While man may find the divinities 'sufficient' for certain needs, something continues to warn him that 'sufficiency' is only in Deity [Supreme Being] .... The divinities are only means to an end and not end in themselves.

In African religious ontology, especially among the West African people, the concept of divinity is well established. Divinities are so many that their number seems not to be known. This concept has made so many scholars to believe that African religion is either pantheism or polytheism. Those who believe that African religion is pantheistic are of the view that Africans see spirit in everything including wood, tree, fire, and others. Though this may be true but Africans do not see these spirits as deserving worship. They still have a strong place for the Supreme Being whom they revere in a special way, and whom they believe is unique.

On the other hand, those who see African religion as being pantheistic have failed to understand that "polytheism is a qualitative and not quantitative concept. It is not a belief in a plurality of gods but rather the lack of a unifying and transcending ultimate which determines its character" (Tillich 246). A careful study of this definition will reveal that in Africa, though there are many gods, yet there is One Supreme God who is worshipped above all-others. This means that the One Supreme God believed in Africa becomes the unifying and transcending ultimate who therefore determines the character of every other activity, showing that polytheism cannot be the right term to describe the type of religion practiced in Africa. Edward E. Evans Pritchard recognized that Nuer religion should not be seen as either monotheistic or polytheistic. He explains that it could be regarded as both depending upon the context. In his words,

It is a question of level, or situation of thought rather than of exclusive types of thought. On one level, Nuer religion may be regarded as monotheistic, at another level polytheistic; and it can also be regard as totemistic (52).

Francis Deng has also seen the religion of the Dinka people as monotheistic. He explains that to Dinka people, their Supreme God, Nhiali "is One" and that all other deities and spirits are identified with this "Over-All God" (51). We therefore agree with 
Idowu and Deng that African traditional religion is "Unitary Monotheism". This is a kind of unitary theocratic government (Idowu, African Traditional Religion ... 168). A government where powers are delegated to various deities or divinities for the governance of the universe, and they bring report to the Supreme Being at intervals.

Spirits in African Religious Ontology: In African traditional religion, the concept of spirits is well defined. This is because Africans believe in, recognize and accept the fact of the existence of spirits, who may use material objects as temporary residences and manifestations of their presence and actions through natural objects and phenomena (Idowu, African Tradition Religion ... 173).

This does not mean that traditional religion in Africa was an alienation in which "man felt himself unable to dominate his environment, in the grip of ghosts and demons, under the spell of the awe-inspiring phenomena of nature, a prey to imaginary magical forces or cruel and capricious spirits" (Shorter 49). What we are stressing here is the fact that Africans, though they believe in the existence of spirits, are not being taken captive by this belief so that they do not consider other materialistic elements in the universe.

When we refer to spirits in African religious ontology, we are not referring to divinities or to ancestors, but to "those apparitional entities which form separate category of beings from those described as divinities" (Idowu, African ... 173). They are considered as "powers which are almost abstract, as shades or vapours which take on human shape; they are immaterial and incorporeal beings" $(173,174)$. As immaterial and incorporeal, it is possible for them to assume various dimensions whenever they wish to be seen

These spirits are created by God but differ from God and man. Man has in various occasions addressed these spirits anthropomorphically by attributing human characteristics such as thinking, speaking, intelligence and the possession of power which they use whenever they wish.

Spirits that we are looking at in this part of the work are the "'common' spiritual beings beneath the status of divinities, and above the status of men. They are the 'common populace' of spiritual beings", (Mbiti, African Religions ... 78).

Origin of Spirits: In African religions, there are three main sources of spirits.
1. Some believe that spirits are created by the Supreme Being as a special "race" of their own. As a race of their own, they continue to reproduce their kind and increase in number until they have become myriads in number.

2. Others in Africa are different in their thinking as per the origin of spirits. This second group "believe that the spirits are what remain of human beings when they die physically" (Mbiti, Africa Religion... 79). To this group, this "becomes the ultimate status of men, the point of change or development beyond which men cannot go apart from a few national heroes who might become deified" (79). This then means that the ultimate hope of man is to become a spirit when he dies.

3. The third source of spirit is animals that died. In Africa, some societies believe that animals have souls and spirits which continue to live with the spirits of dead men after they died. In this way, the world of the spirit is a picture of the material world where humans and animals live.

Nature of Spirits: Spirits are nondescript, immortal and invisible entities. This is because they do not posses material body through which they could be seen but they may incarnate into any material thing in order to make themselves seen for any reason or purpose.

People have however experienced their activities and many folk stories in Africa tell of spirits described in human form, activities and personalities, though sometimes, these descriptions are exaggeration created by the elders to teach special lessons. Since they are invisible, these spirits are thought to be ubiquitous, so that a person is never sure where they are or are not (Mbiti, African... 79).

Spirits do not have any family or personal ties with human beings, and so cannot be regarded as the living dead. This is why people fear them, although intrinsically speaking spirits are strangers, foreigners, and outsiders in the category of things.

Ontologically, spirits are a depersonalized and not a completion or maturation mode of existence. The spirit mode of existence according to Mbiti "is the withering of the individual, so that this personality evaporates, his name disappears and he becomes less and not more of a person: a thing, a spirit and not a man any more" (Africa Religion... 79). 
Majority of people in Africa believe that spirits dwell in the woods, bush, forest, and rivers. Others hold that spirits dwell in mountains, hills, valleys or just around the village and at road junctions. Spirits are in the same environment with men. This means that man has to try in one way or the other to protect himself from the activities of the spirits knowing that the spirits are stronger than him. He uses the various means available to him such as magical powers, sacrifices, and offerings to appease, control and change the course of their action.

Man's Relationship with Spirits: A further study of the activities of the spirits shows that they may cause terrible harm on men. This they do through causing madness or epilepsy and other terrible sickness.

In some cases they may possess people causing them to prophesy. Mbiti explains that "During the height of spirit possession, the individual in effect loses his own personality and acts in the content of the 'personality' of the spirit possessing him (African Religions... 82). The spirits may chose to drive the person away making him to live in the forest. It may give the person information for the larger society in the case of a prophet or soothsayer. When spirits possession is noticed, the traditional doctors and diviners may be called to exorcise that spirit from the person thereby setting him free from his captor.

Among the disastrous spirits that rule in African society is the spirit of witches. To Africans this spirit is real, active and powerful yet very dangerous and disastrous in its actions and activities. Elsewhere, Idowu explains, concerning the concept of witchcraft thus:

African concept about witchcraft consist in the believe that the spirits of living human beings can be sent out of the body on errands of doing havoc to other persons in body, mind or estate; that witches have guilds or operate singly, and that the spirits sent out of the human body in this way can act either invisibly or through a lower creature an animal or a bird (African Traditional Religion... 175,176).

This concept does not require laboratory test for scientist to believe. This is because the realm of spirits is a realm that transcends scientific scrutiny. It is believed among Africans and that is all that matters.

The guild of witches meets regularly for their ceremonies in forests, on trees or under trees, in open places or at the junction of the roads in the middle of the night. This meeting is done at the soul or spirit level meaning that the spirits leave the body of the witches in form of a particular bird or animal. Idowu reiterates the purpose of this meeting as

To work havoc on other human beings; and the operation is the operation of spirits upon spirits, that is, it is the ethereal bodies of the victims that are attacked, extracted, and devoured; and this is what is meant when it is said that witches have sucked the entire blood of the victim. Thus, in the case of witches or their victims, spirits meet spirits, spirits operate upon spirits, while the actual human bodies lie 'asleep' in their homes (African Traditional Religion 176).

Another concept of spirit that is prevalent in Africa is that of the guardian - spirit or man's double. The belief here according to Idowu is either that the essence of man's personality becomes a sort of split entity which acts as man's spiritual counterpart or double; or that the guardian-spirit is a separate entity. The Africans believe that man has a guardian spirit which if it is good, works to bring prosperity and good luck to its double but if the guardian spirit is not in good state, it will rather bring obstacle to the ways of its double.

This spirit is known by many names in Africa. Yoruba people call it ori, Igbo people call it chi, while the Edo people call it ehi. It guards one's steps leading the one to his/her destiny in life. In most cases, it is this spirit that helps to wade off evil spirits that may want to derail the individual from achieving his ultimate in life. This is why most Africans will make sure they sacrifice and appease their guardian - spirit whenever they want to take any important decision or they want to go on a journey.

What we are saying here is that in African traditional religion, the place of spirits is very prominent. This does not mean that Africans are Pantheist but it only means that they recognize the role spirits are playing in human life either positively or negatively and they try to keep them at bay using tools available to them such as magic, divination, exorcism, prayers, sacrifice and others.

\section{CONCLUSION:}

We have submitted in this work that the Supreme Being has a strong place in the African ontology. He is regarded as an uncreated, self existent, unchanging, and reliable Being whose power transcends all powers. He is seen as the Creator, 
Omnipotent, Omniscient and Omnipresent Being who is immortal and directs human affairs. In Africa, $\mathrm{He}$ is worshiped in most places without a temple and without an image attributed to $\mathrm{Him}$ because $\mathrm{He}$ is beyond human understanding and is unique showing that there is none like Him.

This Supreme Being according to African ontology has so many deputies who work with Him in the unitary theocratic governance of the universe. These deputies are regarded as divinities. They are functionaries and ministers whose duties are to carry out the full instructions of the Supreme Being. They do not have absolute power or existence. This is because their lives and existence is derived from the Supreme Being. They are created beings and so are subordinate to the Supreme Being in all matters. They can also be regarded as manifestations of the attributes of the Supreme Being. Africans have temples and shrines dedicated to these divinities even though they are seen as intermediaries between men and the Supreme Being.

There are also the spirits who are either created as a race of their own or as the ultimate end of men who died on earth. Some of these spirits cause havoc on humans and so man uses many methods or tools to wade them off. The belief in guardian-spirit is also prominent in Africa.

We are therefore of the view that in African traditional religious ontology, God-Supreme Being, divinities and spirits exist and play crucial role in that mode of existence which they belong and on humans on earth.

\section{REFERENCES}

Awolalu, J. Omosade and Dopamu, P. Adelumo. West African Traditional Religion. Ibadan: Onibonoje, 1979.

Brown, David A. A Guide to Religions. London: SPCK, 1975.

Deng, Francis Mading. Africans of Two Worlds. New Haven: Yale UP, 1978.

Ekeopara, Chike Augustine. African Traditional Religion: An Introduction. Calabar: NATOS Affair, 2005.

Evans - Pritchard, Edward E. Nuer Religion. Oxford: Oxford UP, 1956.

Idowu, E. Bolaji. African Traditional Religion: A Definition. London: SCM, 1973.

Oludumare: God in Yoruba Belief. London: Longmans, 1962.

Mbiti, John S. African Religions and Philosophy. London: Heinemann, 1969. Concepts of God in Africa. London: SPCK, 1975. Introduction to African Religion. London: Heinemann, 1975

Njoku, Francis O. C. Essays in African Philosophy, Thought \& Theology. Owerri: Claretian Institute of Philosophy \& Clacom Communication, 2002.

p'Bitek, Okot. African Religions in Western Scholarship. Kampala: East African Literature Bureau, 1970.

Ray, Benjamin C. African Religions. New Jersey: Prentice Hall, 2000.

Shorter, Aylward W. F. African Culture and the Christian Church. London: Geoffery Champman, 1978.

Tillich, Paul. Systematic Theology, Vol. One. Chicago: Chicago UP, 1951.

Werner, Alice. Myths and Legends of the Bantu. London: Harrap, 1933 